First Peoples Child \& Family Review

An Interdisciplinary Journal Honouring the Voices, Perspectives, and Knowledges of First Peoples through Research, Critical Analyses, Stories, Standpoints and Media Reviews

\title{
Children for Social Justice
}

\section{Jeff McCrossin}

Volume 7, Number 1, 2012

URI: https://id.erudit.org/iderudit/1068864ar

DOI: https://doi.org/10.7202/1068864ar

See table of contents

\section{Publisher(s)}

First Nations Child and Family Caring Society of Canada

ISSN

1708-489X (print)

2293-6610 (digital)

Explore this journal

Cite this article

McCrossin, J. (2012). Children for Social Justice. First Peoples Child \& Family Review, 7(1), 40-51. https://doi.org/10.7202/1068864ar

\section{Article abstract}

It is often assumed that children lack the developed capacity to understand complicated political issues (for example, Arendt, 1959; Pearce, 2011; and Warmington, 2012a, 2012b). This assumption is contested through a review of the literature examining adult conceptions the child, and children's rights to political participation, citizenship, and direct representation (Steffler, 2009; Wall \& Dar, 2011; Wyness, Harrison, \& Buchanan, 2004). A variety of historical and contemporary examples of children engaging in social justice campaigns and movements are provided (Elshtain, 1996; Milstein, 2010; Smith, 2012; Traubman, 2005; Bergmar, 2010). A potential means for supporting children in social justice engagement is explored through social justice education (Dover, 2009; Kelly \& Brooks, 2009).
This document is protected by copyright law. Use of the services of Erudit (including reproduction) is subject to its terms and conditions, which can be viewed online.

https://apropos.erudit.org/en/users/policy-on-use/ 


\title{
First Peoples Child \& Family Review
}

An Interdisciplinary Journal Honoring the Voices, Perspectives and Knowledges of First Peoples through Research, Critical Analyses, Stories, Standpoints and Media Reviews

Volume 7, Number 1, 2012, pp. 40-51

\section{Children for Social Justice \\ Jeff McCrossin \\ MSW Student, Carleton University, Ottawa, ON, Canada}

\begin{abstract}
It is often assumed that children lack the developed capacity to understand complicated political issues (for example, Arendt, 1959; Pearce, 2011; and Warmington, 2012a, 2012b). This assumption is contested through a review of the literature examining adult conceptions the child, and children's rights to political participation, citizenship, and direct representation (Steffler, 2009; Wall \& Dar, 2011; Wyness, Harrison, \& Buchanan, 2004). A variety of historical and contemporary examples of children engaging in social justice campaigns and movements are provided (Elshtain, 1996; Milstein, 2010; Smith, 2012; Traubman, 2005; Bergmar, 2010). A potential means for supporting children in social justice engagement is explored through social justice education (Dover, 2009; Kelly \& Brooks, 2009).
\end{abstract}

\section{Introduction}

A recent Globe and Mail blog post (Pearce, 2011) asks readers to consider the "irresponsibility" of parents taking children to protests. Pearce (2011) reports that Toronto "City Hall was swarmed with a mini-army of babies, toddlers and children whose parents had brought them to protest potential cuts to city-run daycare programs." This post raised questions about children's right to protest, their capacity to understand political issues, and how adults conceptualize children. This article will attempt to respond to such questions by putting common concerns regarding children and political action into the context of social justice.

As indicated by Pearce (2011) and others (Arendt, 1959; Warmington, 2012b), some facets of society consider the child to be a blank slate, isolated in the private or familial world without the developed capacity to make sense of complicated political issues. Instead, the position taken in this article is that children are already political individuals influenced by private and public spheres through interdependence with adults in their lives (Elshtain, 1996; Kelly \& Brooks, 2009; Milstein, 2010; Wall \& Dar, 2011). Children have the right to make a difference through political participation, citizenship, and direct representation (Wall \& Dar, 2011). As will be discussed below, children throughout history have shown their capacity to break new ground toward equity and social justice. Conceptual models of the child will also be discussed in relation to how adults view children engaged in social justice. Additionally, social justice education will be examined, through a limited review of the literature, as a potential means for advancing social justice

Corresponding author:

Jeff McCrossin, jeff.mccrossin@gmail.com engagement for children. Finally, arguments will be made for a wider interpretation of children's rights in relation to political power. 


\section{Children Engaging in Social Justice}

Children were on the front lines in the movement to end segregation in the southern United States. Responding to their involvement, political theorist Hannah Arendt (1959, cited in Elshtain, 1996) expresses concern that adults are ridding themselves of their responsibility to provide guidance to children. She asks, "Have we now come to the point where it is the children who are being asked to change or improve the world? And do we intend to have our political battles fought out in the school yards?" (Arendt, 1959, p. 50). She wonders how children could be charged with the task of integration if generations of adults were unable to quell the unrest between the black and white communities in the south.

Arendt's (1959) argument is entrenched in her vision of isolated private, public, social, and political spheres. Children, according to Arendt, should exist only in the private sphere, protected under parental guidance. Elshtain (1996) reiterates Arendt's fear that,

If parents collapse, or are stripped of their authority in relation to children, the result will be more conformism of children with their peer group, or age cohort, and a growing homogenization of society. Those capable of resisting will likely be few and under tremendous pressure to succumb to the wider surroundings (p. 15-16).

In Arendt's (1959) view, only adults are able to be individuals as children are incapable of resisting conformity. Arendt appears to see children as benighted vessels for which parents and educators needed to provide teachings relative to the world in which they were born. According to Elshtain (1996), Arendt despised progressive education "in which children are enjoined to create their own environment for learning, free from adult authority" (p. 17). She felt that this type of education encouraged abandonment and betrayal of children. Arendt provides examples of children and youth being used as a political force by Hitler during the Second World War. These children under Hitler's command were "intimidating, shaming, humiliating, betraying, and exposing adults, their own parents and teachers, for insufficient ideological ardor" (Elshtain, 1996). Arendt later concedes that black children of the south were in a dissimilar position from Jewish children in Nazi Germany. The context and outcomes were clearly different.

A more recent criticism of children actively engaging in social justice campaigns (and more outspoken than that of Pearce, 2011) appeared online in May 2012 in Sun News, the right-wing media organization website. Joe Warmington (2012b) reports about young students from The Grove Community Alternative School in Toronto engaged in a project raising concerns over the proposed Enbridge pipeline in western Canada. The children crafted a pipeline showing potential negative social and environmental impacts of the Enbridge pipeline and put it on public display. The story includes a quote from the school's press release for the event, "Children have a strong sense of justice and empathy.... They recognize the unfairness of putting a pipeline through indigenous territory without consent." In a similar report, the same author alleged that the teacher, "with ear rings and a ring through his nose," was "indoctrinating" the students (Warmington, 2012a). He further argues that, at eight years old, children should not be aware of social injustice, "or have an opinion on anything" (Warmington, 2012b). However, being unaware of social injustice does not preclude capacity to understand it (Wyness et al. 2004). Warmington (2012b) suggests that perhaps the Children's Aid Society should be notified, implying that the teacher's efforts to promote social justice education were abusive in nature. Although Warmington provides no evidence to legitimize his claims, he argues that his position reflects that of hundreds of readers who are "disgusted" by this alleged abuse of children (2012b). 


\section{Children for social justice}

Regardless of whether adults accept the idea of children as political individuals, examples of children engaging in inherently political social justice campaigns span the globe, and date back over 100 years.

In 1903, Mother Jones marched 125 miles with 300-500 children to the summer home of then President Theodore Roosevelt to protest wages and conditions of child labour (Elshtain, 1996). This is in opposition to Arendt's (1959) notion that children should not be dragged into the public realm. But in this case, Elshtain notes, "children [were] politicized, drawn into protests, strikes, marches and potential danger in order that they may return to the schools, neighborhoods and playgrounds where they belong" (p. 20). Mother Jones showed that the children were already in full view of the public; their political actions were necessary to achieve greater social justice. Mother Jones's message to her critics (related by Elshtain, 1996, p.20): "You think taking children on protests is shameful? No, it is shame that drives them to protest."

Elshtain (1996) also describes the "Children's Miracle" of 1963, where children in Birmingham, Alabama, protested in support of desegregation. The children, as young as six years old, refused orders by police to disband and were led to prison cells. Elshtain describes the cascading effect of the actions taken by these children:

The campaign gained momentum. Soon 958 children had signed up indicating their willingness for jail and some 600 were in custody. Protest speakers extolled the courage of children. More children took to the streets and parks. Scenes of children being hit by projectiles of water from firehoses and lunged at by police dogs helped to galvanize the American conscience (p. 21).

While the white leaders of Birmingham were concerned that children were being used as political tools, Martin Luther King Jr. praised the courage shown by the children for standing up for what they believed in.

In Pakistan, Iqbal Masih began working as a debt slave in a carpet factory when he was about five years old (Bergmar, 2010). Iqbal became known around the world for standing against those who forced him into child labour and for successfully encouraging other children to join him. Iqbal was murdered under mysterious circumstances in 1995, but was posthumously awarded the World Children's Prize for the Rights of the Child (Bergmar, 2010) and was the inspiration for child-activist Craig Kielburger, founder of Free the Children, an international charitable organization that builds schools (among other initiatives) in developing nations (Steffler, 2009).

In May 2012, children in Israel stood against the massacre of 50 Syrian children during that country's ongoing civil war (Benari, 2012). The children held a candlelight vigil outside the Russian embassy in Tel Aviv, signifying an understanding of complex global politics.

In Buenos Aires in 2004, a class of fifth-grade children (ages 10-15) managed to get their teacher dismissed after she had mistreated a number of students (Milstein, 2010). Other teachers and staff at the school initially dismissed that particular class of children as being "difficult," "undisciplined," and having "learning problems." Despite coming from poor neighbourhoods and struggling academically, the students demonstrated their capacity to understand that they were being treated unjustly. In response to repeated acts of violence toward them, the students held a protest in their classroom with rhythmic clapping and shouts of "Justice!" akin to frequent local "street mobilizations" in which community members had demanded solutions to violence against youth (Millstein, 2010, p. 139). Their collective action in the classroom that day gathered the support of their parents, other teachers, and the headmistress of the school, leading to the dismissal of their teacher. Milstein attributes much of the students' success to "taking their 
problem out of the 'private' classroom and into the 'public' school," thus extending the range of their voices.

In 2005, a group of children of foreign workers in Israel attended a Supreme Court hearing regarding a petition for their legal residency status (Traubman, 2005). Children participating in these legal hearings received experiential learning opportunities, through exposure to the court system, but also through challenging inequitable systems of power. In a similar fashion in February 2012, hundreds of Canadian elementary and high school students, supported by their teachers and families, attended a Federal Court judicial review of a human rights case regarding First Nations child welfare. In a coordinated gathering on Parliament Hill, they delivered letters objecting to inequality in First Nations child welfare, health care, and education to their political representatives (Smith, 2012).

Shannen Koostachin, from the Attawapiskat First Nation in Northern Ontario, began a campaign in 2008 for equitable education for First Nations children (About Shannen, 2012). Though only 12 years old, Shannen understood that First Nations children were not being treated fairly, and led hundreds of children from across Canada into peaceful action through speeches, letter writing, and social media. Shannen passed away in 2010, but thousands of child and adult supporters have joined the social justice campaign called Shannen's Dream (About Shanne, 2012), perpetuating her efforts.

It was estimated that over a thousand school-aged children gathered on Parliament Hill (and in 50 communities across the country) on June 11, 2012 in support of Shannen's Dream and a number of other campaigns facilitated by the First Nations Child and Family Caring Society of Canada for a walk dubbed the Our Dreams Matter Too (Blackstock, 2012). On the fourth anniversary of the Prime Minister's apology for Residential Schools (Harper, 2008), the crowd of First Nations and non-Aboriginal children stood in solidarity to deliver letters they had written, asking the government to provide equitable services-including those related to health, education, and child welfare-to all children within Canadian borders. Four years after the apology, First Nation children and families continue to be treated as second class citizens by the Government of Canada. This protest took an inherently different approach to instigating change than those initiated by adults. Rather than debating how legislation such as the Indian Act should change, or discussing the complicated relationship between First Nations and the Government of Canada, the children articulated their concerns on the basis of values, such as equality, fairness, and non-discrimination. Children in attendance also received messages of solidarity between First Nations and non-Aboriginal Canadians, rather than charity or pity that would perpetuate a false hierarchy.

\section{Contradictions in Acceptance of Political Children}

How can we commend children engaged in social justice campaigns such as those led by Mother Jones, Martin Luther King Jr., and young leaders such as Shannen Koostachin and Iqbal Masih, while vehemently opposing political actions of children led by genocidal tyrants like Hitler, Pol Pot, Qaddafi, and others? Elshtain (1996) explains that the contexts are distinct:

We blanch when we see children giving a Nazi salute. We are moved when we see children singing hymns and marching off to jail in a desegregation protest. Are we bereft of ways to adjudicate these and other cases of political children? Does it come down to whether we are proNazi or anti-segregation? (p. 23). 


\section{Children for social justice}

In some circumstances, such as the Children's Miracle of 1963, children display incredible "clear sighted political courage;" in others, "fear and ferocious zealotry" (Coles, 1967 as cited in Elshtain, 1996, p. 20-21).

Young anti-abortion protesters are key contemporary examples of children engaged in political action that is disapproved by the more liberal base of western society (Elshtain, 1996). As a subject of political action, abortion is more morally ambiguous than desegregation in schools. According to Elshtain, the response of critics opposing young anti-abortion protesters has been similar to that of those opposing segregation. There appear to be fears that children do not have the capacity to be pro-choice or pro-life, and are being inappropriately led or even abused by the adult anti-abortionists. Elshtain (1996) criticizes this approach to framing the argument:

The mistake pro-choice critics of pro-life child protesters make in all of this is their politically repressive embrace of the language of 'child abuse' and their representation of these children as manipulated automatons with 'no concept of what they're doing', (p. 23).

An argument such as this directly contradicts those made by the liberal base for including children in those social justice movements which they support. Furthermore, arguing that children are being brainwashed into joining anti-abortion protests contradicts evidence that children have the capacity to develop their own political opinions (Wyness et al. 2004).

It would appear that, contrary to Arendt's (1959) concern of shedding public light on children, the primary issue with children being engaged in social justice action rests within the particular campaign and the manner in which children are engaged. Elshtain (1996) rejects Arendt's notion that children exist within isolated spheres, waiting to be led into one or another by the adults in their lives. She acknowledges that adults clearly can and do have an impact on children, but in a manner that merely influences-not controls-the pre-existing public, private, political, and social aspects of a child's life. Assuming complete innocence and naivety of children serves only to devalue a major facet of society and slow progress of social justice efforts. Wyness et al. (2004) note that "innocence equates to vulnerability, which legitimates children's political exclusion and adults' right to talk on behalf of children" (p. 85).

Kelly and Brooks (2009) describe the protection of childhood innocence as an oft-cited concern that prevents new teachers from engaging young children in social justice education. The authors argue against this notion that children are blank slates: "children's identities are culturally produced" which, "emphasizes that they are active in this process, not just passively taught ideas and values by adults" (Kelly \& Brooks, 2009, p. 204). Furthermore, assuming innocence of a child creates concerns around engagement and participation. Wall and Dar (2011) explain: "The danger in assuming that every word the child speaks is unfiltered and unmediated by those around her and is the only way of getting at a child's perspective, complicates the understanding of what participation of children can really include" (p. 380).

\section{Models of the Child}

To develop a hypothesis of whether children should be involved in or educated for social justice, or to defend such a hypothesis, it is necessary to examine how the child is viewed by power-wielding adults in the public sphere (Wyness et al. 2004). The concept that children are benighted vessels, or blank slates is entrenched throughout society, often in the context of childhood innocence and through the several models of the child in relation to social justice (e.g., the universal child, the child as savior/victim, the colonized child, and the globalized child 


\section{First Peoples Child \& Family Review, Volume 7, Number 1, 2012}

as described by Steffler, 2009). Examining these models permits us to explore how adults view children in political contexts.

\section{The universal child}

Despite convincing arguments suggesting that children are political individuals with the capacity to be active citizens (Elshtain, 1996; Wall \& Dar, 2011; Wyness et al. 2004), the universal child model is persistently used by literary, political, and cultural forces as a symbol to "erase national borders in order to teach and promote equality and social justice" (Steffler, 2009, p. 113). This model uses children's characteristics such as innocence, fragility, and universality to allow the consumer of the model to relate to the child. The universal child is frequently displayed as a victim and exploited to evoke empathy in campaigns to end famine, war, and poverty (Steffler, 2009, p. 113).

\section{The child as saviour}

In the model of child as saviour, the child is considered morally superior to adults, and is placed in a position to make a difference where adults have otherwise failed (Steffler, 2009). The child takes it upon him- or herself to "save society." While commendable, Steffler warns the danger "...is the valorization, entrenchment, and prolonging of the Canadian child as the enlightened donor, which requires, of course, the continued positioning of the "other" child as recipient" (p. 119).

Steffler (2009) reviews the concept of children saving children, citing Craig Kielburger as a prime Canadian example. As a 12-year-old child, Kielburger founded Free the Children. He was inspired to create the organization after learning about Pakistani child-labourer Iqbal Masih. The organization has received criticism for its "patronizing Christian overtones in the disturbing discourse of Masih as martyr/victim and Kielburger as savior/crusader" (p. 117). Furthermore, "the crusader empathizes with the labouring or needy victim, who tends to remain silent in his passive role as the "deserving" recipient of the activism" (p. 117).

This interpretation supports a notion that children living in third world conditions are blank slates for sympathetic children in western nations to fill with their own perceptions of what the child should be: "Children saving children entrenches the dependent and colonial roles of donor and recipient, saviour and victim, in those seen by society as carrying the most potential and bearing the most suffering" (Steffler, 2009, p. 118). Moreover, the donor or saviour is often rewarded or recognized for acting in a moral way (Steffler, 2009).

\section{The colonized child}

Intrinsically linked to the child as saviour model, is the colonized child model (McGillis \& Khorana, 1997). Children, according to McGillis and Khorana (1997), are "the most colonized persons on the globe" (p. 7). In this model, children do not share the same opportunity to succeed and impose their political will due to being colonized by adults (Wall \& Dar, 2011). 


\section{Children for social justice}

\section{The globalized child}

There is evidence of political and social influence from adults in Canadian children's literature that perpetuates this colonization of children. Steffler (2009) provides an example of a Canadian author, Deborah Ellis, who writes children's books with an international humanitarian theme. Ellis wrote fictional stories about children living in "desperate" situations in Malawi, Afghanistan, and Bolivia. While Ellis donated the proceeds to charities benefiting the children upon whom her stories are based, concerns have been raised over the appropriateness of the material. Steffler brought to light the potential for exploitation and misrepresentation of children's voices, and complacency toward social action:

... the donations potentially free the author and reader from any discomfort or guilt that may arise as a result of consuming the miseries of the real children upon whom the fictional children are based.... The recognition Ellis has received through the many awards and honours bestowed on her and her work ... reflects a self-congratulatory "good" feeling of a public that believes it can vicariously make the world a better place through reading (p. 110).... There are problems inherent in such assumptions of identification and empathy, the most disturbing being the ease with which the reader is supposed to negotiate and flatten difference (p. 112).

Rather than inspiring children to engage in action for social justice, these books and similar approaches to social justice education may only result in desensitization and apathetic reactions. Steffler (2009) argued that this is just one example in a recent trend to create the notion of the "globalized child" (p. 111) in children's literature. The use of children's books to push political agendas and "ideals of national citizenship" (Steffler, 2009, p. 111) is not a recently developed phenomenon. Steffler pointed to Canadian ideals of multiculturalism being widespread within children's literature in the 1970s. Carpenter (1996, as cited in Steffler, 2009) found the attempt to shape the nation through imposing an outside representation of minority populations futile:

... the attempt to promote the ideal "multicultural" Canadian citizen through didactic children's literature naively assumes that children will enact what they read, are blank slates who passively receive culture because they have no culture of their own, and will automatically develop tolerance simply as a result of being informed (Carpenter 1996, cited in Steffler, 2009, p. 112).

\section{Social Justice Education}

Paulo Freire's text, Pedagogy of the Oppressed (1970, interpreted in Van Gorder, 2008, p. 21), suggests that education systems need to provide opportunities for children to create a "world of possibilities' instead of serving the status quo by imprisoning naturally inquiring and curious minds in cells of silence and submission." Resulting from decades or even centuries of prejudicial social developments,

social inequities are magnified by hegemonic classroom practices that reproduce and reinforce the cultural and educational traditions of white, middle-class communities at the expense of non-dominant cultures' educational traditions" (Dover, 2009, p. 507).

As described by Dover (2009), "teaching for social justice is the attempt by classroom teachers to use their position in the classroom to affect meaningful change within and despite current educational conditions and mandates" (p. 518). Dover lays out a conceptual framework for teachers for social justice. According to this framework, teachers must: 
First Peoples Child \& Family Review, Volume 7, Number 1, 2012

(1) assume all students are participants in knowledge construction, have high expectations for students and themselves, and foster learning communities; (2) acknowledge, value, and build upon students' existing knowledge, interests, and cultural and linguistic resources; (3) teach specific skills and bridge gaps in students' learning; (4) work in reciprocal partnership with students' families and communities; (5) critique and employ multiple forms of assessment; and (6) explicitly teach about activism, power, and inequity in schools and society (p. 518).

Kelly and Brooks (2009) posit that education for social justice should be engaging and come from an anti-oppressive approach. It should be taught in a manner that enables teachers to "enact inclusive curricula and pedagogies while simultaneously adapting these to the cognitive, emotional, and political-evaluative capacities of their students" (p. 203). The authors state concerns over the use of the human relations approach to teach social justice. This approach manifests as anti-bullying interventions and teachable moments of tolerance or acceptance of difference. It presents issues such as racism as personal in nature instead of resulting from structural inequities. Rather than engaging students proactively in larger social change as active participants in citizenship, the human relations approach reactively addresses social justice concerns by taking a zero-tolerance approach to prejudicial attitudes, comments, or other behaviour without discussing thoughts and feelings from which they originated. This distinction between the human relations and anti-oppressive approaches, as described by Kelly and Brooks (2009), highlights the importance of defining social justice education in curriculum in order to have the greatest positive impact on children. Teachers have the duty to encourage students to critically explore their moral values and challenge their beliefs, even when in opposition to those of their parents (Kelly \& Brooks, 2009).

In a small study $(\mathrm{n}=12)$ of pre-service teachers in western Canada, Kelly \& Brooks (2009) found that new teachers base their understanding of children's capacity to understand political concepts on Piaget's concept of readiness. The reliance on this concept has

... unnecessarily helped to restrict the equity-related work that teachers envision by implying that it is developmentally inappropriate for younger children (Kelly \& Brooks, 2009, p. 204).

Some teachers in the cited study avoided "heavy" or "iffy" subjects (an example of an "iffy" subject was homosexuality), not only due to concerns of the students' capacity, but also due to potential negative feedback from parents. This aversion to social justice education is contrary to research that "indicates that most parents and students support socially just content and policy" (Dover, 2009, p. 515). There is little, if any, evidence to suggest that young children lack the capacity to understand and handle issues of social justice (Kelly \& Brooks, 2009), yet teachers and other adults frequently use models of the child described earlier to discredit their capabilities (Wyness et al. 2004). In the same study, teachers

... perhaps paradoxically ... explained that deliberate teaching about respect might be easier in the early grades, because children's biases would be less "ingrained" (Kelly \& Brooks, 2009, p. 213).

Similar to a child's right to direct political representation, it has also been argued that a child's right to education should not be misconstrued as a parental liberty right (Grover, 2007), meaning parents do not have the right to dictate the addition of prejudicial, or exclusion of socially just, curriculum.

Available research suggests, contrary to critics, that education for social justice builds on fundamental academic skills. In a literature review of the impact of education for social justice, 


\section{Children for social justice}

Dover (2009) found evidence of positive impacts in the areas of academia, behaviour and motivation, and attitudes. While Dover reported that the evidence available was commonly limited by small sample sizes, potentially confounding variables, and anecdotal in nature, he argued that education for social justice can be effectively integrated into standardized curricula. Furthermore, Dover argued that "comprehensive teaching for social justice is an integrated pedagogical, ideological, and curricular approach to teaching that includes rigorous contentbased curriculum" and so, evidence found within studies of integrated social justice and other curriculum maintains its value.

Examining the impact of social justice education is not straightforward because definitions and teachers' understanding of social justice differ (Dover, 2009; Kelly \& Brooks, 2009). Some scholars are concerned that the term "social justice education" has become trendy without a clear consensus on its definition or method of implementing it into curriculum (Kapustka, Howell, Clayton, \& Thomas, 2009).

\section{Children's Rights to Participation and Direct Representation}

The United Nations Convention on the Rights of the Child (UNCRC) provides guidance to states around the participation rights of children. According to the UNCRC, children have the right to be heard, to freedom of expression, thought and assembly, privacy, and access to information (United Nations Convention on the Rights of the Child, 1989). The Convention does not provide sufficient grounds for the political inclusion of children (Wyness et al. 2004). Terms often used by states in relation to a child's capacity to understand and engage in politics and government are participation and citizenship. However, these terms may not be sufficient means for children to be active and engaged in social change. Wall and Dar (2011) suggest that both the terminology and the political systems that use them undermine the rights of children. Inherent in their argument is the belief that children need to have an increased role in the development of human rights policies through direct political power. The authors argue that children's rights go beyond those of the UNCRC to include direct political representation, in addition to participation and citizenship.

Participation through agency and voice does not equate to full participatory power (Wall \& Dar, 2011; Wyness et al. 2004). Wall and Dar (2011) explain that children often lack the "political resources, experience, or capital to impose their own perspectives on political life" (p. 380) and are dependent on adults. This dependency should not exclude children from shaping policies around their rights, or reduce their participation to exploitative circumstances under which they are manipulated.

The concept of citizenship is commonly related to characteristics associated with adulthood, such as rationality, autonomy, and impartiality. Wall and Dar (2011) believe this concept to be somewhat accurate:

The idea of political participation as the expression of independent agency or freedoms involves a level of adultism. It assumes a politically independent individual. The reality, however, is that both children and adults are better understood politically as operating within larger networks of social interdependence, in which they both act but also depend on support and inclusiveness (p. 381).

Citizenship is more accurately based on a notion of interdependence between adults and children, while also recognizing the uniquely lived experience of children (Wall \& Dar, 2011). 
Wyness et al. (2004) note that as part of being granted citizenship, children need to be recognized as having "full social status" (p. 84) with rights to self-determination, rather than simply as citizens-to-be.

In a democratic society, power is shared across all facets of society, and not limited to competition of autonomous individuals (Wall \& Dar, 2011). The purpose of increasing the political power of children is to enhance their capacity to challenge governments through accurate and direct representation. Children are the largest group of citizens in society to wield no political power through direct representation (Wall \& Dar, 2011). Not only do children have a right to be different than adults, but they also have the right to make a difference:

A fully child-inclusive model of political representation will combine ... concepts of interdependence and difference in what we call the right to make a political difference (Wall \& Dar, 2011, p. 384).

\section{Conclusion}

There is an underlying assumption in society that "politics is 'adult' rather than child's play" (Milstein, 2010, p. 142). There is little evidence to support this notion, and strong arguments support the expansion of children's rights to include not only political participation and citizenship, but also direct representation (Wall \& Dar, 2011). Children engaged in inherently political social justice campaigns do not exist solely in the political realm. They are still children. Their reliance on adult support does not suggest a need to exclude them from political processes: it suggests that adults need to support the active participation, citizenship, and representation of children through interdependent relationships (Wall \& Dar, 2011; Wyness et al. 2004). The handful of examples of children campaigning for social justice provided in this article, and in Dover's (2009) review of the positive impact of social justice education, provide evidence of the capacity of children to exist as political individuals.

Among the examples found in the literature and the media of children engaging in social justice action, one theme that emerges is outspoken individuals and collectives from disadvantaged circumstances who speak out against maltreatment of themselves and others. Steffler (2009) emphasizes the importance of critically evaluating how children from advantaged circumstances engage in social justice action:

...until the extremely defensive border excluding and sanctifying childhood is broached and the figure of the child as redeemer and saviour critically probed, there will be little movement or change to the artificial constructions and exploitations of the universal/globalized child, who is refused the much needed translation from child to person and from concept to individual (p. 120).

Children and youth motivated to engage in social justice campaigns, or adults dedicated to supporting such efforts, should look for guidance toward models of social justice education, and be explicit about what definition they intend to follow. To that end, a consensus on the definition of the term "social justice education" needs to be agreed upon among scholars and educators. Once a consensus is reached, teachers need to be instructed to integrate it effectively into their curriculum. In response to critics of social justice engagement and education, society must continue to acknowledge the welfare and related rights of children, but adults need to uphold those rights in ways that do not interfere with the interests of children (Wyness et al. 2004). 


\section{Children for social justice}

Intuitively, one could conclude that teaching children to think critically to help shape a more just society would lead to a positive impact on children. An environment where children's opinions are valued and they are included through active participation, citizenship, and meaningful representation, will undoubtedly lead to positive outcomes. While research on the impact of social justice education is limited, the evidence that exists indicates positive effects on academics, behaviours and motivation, and attitudes of children that are exposed to it (Dover, 2009).

\section{References}

About Shannen. (2012). Retrieved from http://www.fncaringsociety.com/shannensdream/about-shannen.

Arendt, H. (1959). Reflections on Little Rock. Dissent, 6 (Winter), 45-56.

Benari, E. (2012, May 21). Children protest Syria massacre outside Russian embassy. Israel National News. Retrieved from http://www.israelnationalnews.com/News/News.aspx/156369\#.T-idg45hBFA.

Bergmar, Magnus (2010). Iqbal Masih. Retrieved from http://worldschildrensprize.org/iqbal-masih.

Blackstock, C. (personal communication, June 2012).

Dover, G. (2009). Teaching for social justice and K-12 student outcomes: A conceptual framework and research review. Equity \& Excellence in Education, 42(4), 506-524.

Elshtain, J. B. (1996). Commentary: Political children. Childhood, 3, 11-28.

Freire, P. (1970). Pedagogy of the oppressed. New York: The Continuum International Publishing Group Inc.

Grover, S. (2007). Children's right to be educated for tolerance: Minority rights and inclusion. Education and the Law, 19(1), 59-70.

Harper, S. (2008, June 11). Statement of apology-To former students of Indian Residential Schools. Ottawa, Canada. Retrieved from http://www.aadnc-aandc.gc.ca/eng/1100100015644.

Kapustka, K. M., Howell, P., Clayton, C., \& Thomas, S. (2009). Social justice in teacher education: A qualitative content analysis of NCATE conceptual frameworks. Equity \& Excellence in Education, 42(4), 489-505.

Kelly, D. M., \& Brooks, M. (2009). How young is too young? Exploring beginning teachers' assumptions about young children and teaching for social justice. Equity and Excellence in Education, 42(2), 202-216.

McGillis, R., \& Khorana, M. (1997). Introductory notes: Postcolonialism, children, and their literature. ARIEL, 28(1), 7-15.

Milstein, D. (2010). Politics is also "child's play." Teaching and Teacher Education, 26, 136-143.

Pearce, T. (2011, September 22). Taking kids to protests-Is it responsible? Globe and Mail Blog. Retrieved from http:// www.theglobeandmail.com/life/the-hot-button/taking-kids-to-protests---is-it-irresponsible/article617674/.

Smith, T. (2012, February 15). Children ask Harper to 'have a heart' and improve education on reserves. The Vancouver Sun. Postmedia News.

Steffler, M. (2009). The production and use of the globalized child: Canadian literary and political contexts. Jeunesse: Young People, Texts, Cultures, 1(2), 109-125.

Traubman, T. (2005, November 28). Foreign workers' children protest at supreme court. Haaretz. Retrieved from http://www.haaretz.com/print-edition/news/foreign-workers-children-protest-at-supreme-court-1.175245

United Nations Convention on the Rights of the Child. (1989). Retrieved from http://www2.ohchr.org/english/law/pdf/ crc.pdf. 


\section{First Peoples Child \& Family Review, Volume 7, Number 1, 2012}

Van Gorder, C. (2008). Paulo Freire's pedagogy for the children of the oppressors: Educating for social justice among the world's privileged. The Journal of Pedagogy, Pluralism, \& Practice, 13, 1-30.

Wall, J., \& Dar, A. (2011). Children's political representation: The right to make a difference. International Journal of Children's Rights, 19(2), 375-392.

Warmington, J. (2012a, May 8). Kids should be educated, not indoctrinated. Toronto Sun. Sun Media. Retrieved from http://www.torontosun.com/2012/05/08/kids-should-be-educated-not-indoctrinated.

Warmington, J. (2012b, May 8). What are they teaching our kids? Sun News. Retrieved from http://www. sunnewsnetwork.ca/sunnews/straighttalk/archives/2012/05/20120508-083920.html.

Wyness, M., Harrison, L., \& Buchanan, I. (2004). Childhood, politics and ambiguity: Towards an agenda for children's political inclusion. Sociology, 38(1), 81-99. 